\title{
Prospective Analysis and Establishing Substantive Truth in Review of Merger Decisions in Court
}

\author{
Dr. Anna Gerbrandy Ph.D.
}

\author{
Aanbevolen citeerwijze bij dit artikel \\ Dr. Anna Gerbrandy Ph.D., 'Prospective Analysis and Establishing Substantive Truth in \\ Review of Merger Decisions in Court', NALL februari 2014, DOI: \\ 10.5553/NALL/.oooo19
}

\section{Introduction}

Legal disputes revolve around facts or: what actually happened. These facts relate to prior action (or lack of action) of one or more of the parties involved in the dispute. When a case is brought to court, parties will further elaborate on the facts that lie at the heart of the legal dispute. They will argue a scenario, a story of the facts, that serves their personal interests or the interests of the administrative body represented. The court subsequently establishes the facts in a judgment: these are the facts as conditioned by the context of the substantive and procedural aspects of the field of law involved. The facts as established by the court are the formal facts. The formal truth thus established should coincide, as far as possible, with the 'true' story - the substantive truth - of what actually happened.

It is therefore safe to say that 'in general lawyers glance back'. ${ }^{\mathbf{1}}$ But not in all disputes. What happens when the 'true' facts are still in the future? Can any real truth be established if the facts have not yet occurred? If this question is to be answered in the negative, what implications does this have for judicial review in administrative procedures? This question will be analysed by examining the Dutch Administrative Court's review of merger decisions of the Dutch Competition Authority (now part of the Authority Consumer \& Market). ${ }^{2}$ The point of departure will be the Dutch legal system, but, as merger cases occur elsewhere in a similar setting, the findings have broader validity and will be recognizable in many jurisdictions. Where necessary, particulars of the Dutch system will be explained. First, I will explore the duty of all Dutch administrative courts to establish the substantive truth of facts in general (section 2), after which I will zoom in on the prospective analysis in competition law's merger control (section 3). I will then reflect on some problematic issues of a court's review in relation to uncertain facts (section 4). Section 5 will contain some concluding remarks.

\section{The court's duty to establish the substantive truth}


Before the question can be answered whether facts can be determined by an administrative court if they have yet to occur, the general legal notion of 'establishing truth' must be clarified. Can a court, in a legal dispute, establish 'true facts'? When does a judge know if she has 'succeeded' in such an endeavour? ${ }^{3}$ It seems to be commonly held that determining real facts is virtually impossible: the court is 'merely' - the quotation marks show that this task is not to be underestimated - required to approximate, as closely as possible, the true facts. This approximation of truth is accepted. If valid, then the quest for true facts is changed into a quest for the terms of the justification of a judgment on evidence (evidence generally relating to facts). In this process, the court is bound to rules of proof and the resulting judgment must be based on procedural norms for establishing facts of law. ${ }^{4}$

It is important to point out the administrative-law context of judicial review. It is also necessary to point out that judicial review, in the Dutch system of administrative law, generally includes a full review of the facts. This includes the power of establishing the facts by the court itself (I will dwell a bit more on this below). In judicial review, the complete administrative decision, a decision of an administrative authority, is under review, although the court will generally limit the review to the grounds proposed. An administrative authority will, of course, often base its decision on existing, historical facts. The court will review these factual findings. According to the (Explanatory Memorandum to the) $A w b$, the General Administrative Law Act, for the court establishing the substantive truth is the point of aim. This is understood as meaning 'that which actually happened' and is in line with the correspondence theory of truth. ${ }^{\mathbf{5}}$ Just to provide some reference points: in its bare essence this is no different from a courts' function in criminal law. It is, however, somewhat different from civil law, where - at least as far as administrative law sees its own role - not the substantive truth, but a formal truth is accepted. ${ }^{\mathbf{6}}$ Clearly different from criminal law, however, is that in administrative proceedings the evidentiary rules are relatively flexible. ${ }^{7}$ Opposed to civil law, administrative courts have autonomous and possibly far-reaching powers in relation to factfinding, although in practice these are not often used. 8 An important difference to both civil and criminal law is that the task of judicial review of administrative decisions is almost always reactive, in the sense that the facts have already been determined in a decision. ${ }^{\mathbf{9}}$ Furthermore, administrative law often involves strict terms in which an administrative body needs to establish a decision. This is certainly true in merger control - which is the topic of this article - where these terms are not only very short, but also final: if the authority has not taken a decision, the merger is deemed to have been allowed.

In this procedural context facts should be proven. As substantive truth must be established, proof must relate to 'true' facts. The court needs to be convinced (to a certain extent) of the (truthfulness of the) facts, before these facts are accepted as a basis for a judgment and the administrative decision involved. However, the court is obviously dependent upon parties in the case, not only with regard to the grounds for appeal but also with regard to the quality of the evidence. Therefore it is not surprising that the court's judgment may create a truth which is not necessarily the substantive truth but a legally established, formal truth.

Sometimes prospective elements are part of an administrative procedure. For example, in assessing an application for subsidizing a cultural institution, expectations regarding the future of that institution also play a role. In a decision 
on a building permit application an assessment of how the future building will look and fit in within the existing situation will be taken into consideration. The evaluation of the actual final situation can, of course, only be done ex post. Nonetheless, even though the decision involves a future element, an assessment of currently known facts suffices, because the relatively short time span and minimal amount of variables (or absence of variables) influencing the future factual situation means that future uncertainty is limited and contained.

In contrast, other decisions are explicitly, and to large extent, based on the assessment of future, complex and uncertain events or developments. In such cases, an assessment - in light of the relevant legal norm - cannot (solely) be based on the actual facts. For example, in some regulatory tariff decisions, tariffs for a profession or a specific service are set for a certain period of time based on different scenarios relating to (future) market developments. ${ }^{\mathbf{1 0}}$ Environmental impact assessments, which need to be performed in large infrastructural projects, ${ }^{\mathbf{1 1}}$ to a certain extent also need to evaluate future events; for example evaluating the influence that the construction of a supermarket or a new ring road will have on traffic flows. ${ }^{\mathbf{1 2}}$ The uncertainty inherent in such assessments stems from the applicable legal norm. In comparison to the examples mentioned above - the subsidy application and the buildingpermit - in this second type of decisions involving future facts, uncertainty is increased exponentially. There is a longer time frame to be considered, which means that multiple variables can play a role in the assessment. ${ }^{\mathbf{1 3}}$

The fact that these decisions relate to future outcomes influences the (possibility of) establishing facts and the ability to determine a substantive truth.This is a truism on a very fundamental level: barring timetravel it is impossible to determine the truth of a future event. ${ }^{\mathbf{1 4}}$ However, a court must base its judgment on facts: reviewing an administrative decision includes review of the facts on which the decision is based. With the judgment, including one where the facts relate to future events, the court establishes a legal truth, a formal truth. Whether or not this formal truth is the same as the substantive truth is not only influenced by procedural rules, but also - and fundamentally - by having to review a prospective analysis.

\section{The place and content of the prospective analysis in competition law}

Like European competition law, the Dutch Competition Act (Mededingingswet, hereafter: $M w)^{\mathbf{1 5}}$ determines that a proposed merger - a 'concentration': a merger, take-over or joint venture - is subject to merger control by the ACM if certain thresholds are met. ${ }^{\mathbf{1 6}}$ Merger control is a form of ex-ante supervision, as a proposed merger needs to be notified to the ACM, which assesses its compatibility with the competition law rules. Where, on the European level, these are the European rules on competition law, governed by the mergercontrol regulation and ex-ante review by the European Commission (hereafter: the Commission), in the national context the procedure of the $M w$ applies. The procedure is covered both by the $M w$ itself and by the procedural provisions of the Dutch General Administrative Law Act, the $A w b .{ }^{17}$ The Dutch competition authority is the relevant administrative authority for decisions in the merger control regime.

Familiar to European competition lawyers is the system of generally having to 
obtain ex ante permission (though the Dutch system is procedurally not an exact copy, these details have no bearing on the exploration of this article). Permission by way of authorization for a proposed concentration will not be granted if the concentration will lead to competition problems: when there is a significant impediment to effective competition, especially as a result of establishing or strengthening a dominant position. ${ }^{\mathbf{1 8}}$ Parties have to apply for 'authorization' (or 'permit': a vergunning), which application is governed by general procedural rules applicable to such decisions laid down in the $A w b$. However, the Mededingingswet provides additional procedural rules, for example by supplying that the deadlines for taking a decision are final: if the ACM does not decide on an application within set terms (which can be extended), this will result in authorization by default. The proposed concentration can then proceed as planned. ${ }^{19}$

\section{Components of substantive assessment}

The substantive assessment of a notified transaction (merger, take-over or joint venture) consists of both an analysis of the current market situation and of an analysis of the market situation that would arise if the concentration would proceed, including its effects on competition. In relation to the theme of this article - substantive truth in prospective analysis - the conceptual difference between these parts of the analysis is important.The difference affects the possibilities for establishing 'true' facts and the route towards establishing these facts by the court (see also section 4 ).

First, the analysis of the market situation before a merger is, logically, an analysis of a current situation. No future facts are involved (step 1 of the assessment). However, the analysis of the post-merger market situation entails assessment of future facts. It consists of two steps: assessment of the market position of parties involved (step 2) and assessment of the effects on or consequences for competition (step 3). Both of these concern future facts, but the degree of certainty in relation to those facts is different.

The first step of the substantive assessment, determining the current market situation, consists of a complex combination of interrelated economic and legal facts and evaluations. Sometimes this step is skipped and the analysis will proceed to a 'direct measurement' of market power: the charting of the (im)possibilities of the merging parties to engage in anti-competitive behaviour, such as price increases (see step 3 of the substantive assessment). ${ }^{\mathbf{2 0}}$ This entails a choice of modelling market behaviour. But in general, assessing the current market situation comprises at least a definition of the relevant market, which is the market on which the parties to the merger are active, and an assessment of their position in that market. Again, a certain model of market assessment is chosen as point of departure. ${ }^{\mathbf{2 1}}$ Though the assessment concerns the current market situation, how to qualify this situation under competition law can depend on the choice of the model. Taking the model as a starting point, the analysis is based not only on primary or simple facts, but also comprises assement of the relevant framework in which the facts should be viewed in order to come to new, more complex facts. ${ }^{22}$

A complicating factor in determining the current situation is that future market behaviour can be used to establish the current situation, depending on the model and method used. For instance, in market analyses, consumer surveys 
about their future behaviour can be used. ${ }^{\mathbf{2 3}} \mathrm{A}$ common model for market definition, the SSNIP-test, also involves future behaviour: what will consumers and producers do in reaction to a small but significant non-transitory increase in the price of a certain product or service? ${ }^{\mathbf{2 4}}$ Will this alter their behaviour? The test can be performed empirically - and then relates to actual and possibly true facts - but often this is not the case: the test is hypothetical. This means that an important part of assessing the current situation is also based on a prospective analysis. The problems that arise in establishing the truth of facts in court are relevant here as well as for the 'real' prospective analysis (see also section 4).

The assessment of what is called the prospective analysis comprises two parts, as set out above. First of all the position of the parties after the concentration must be determined (step 2 of the assessment). Determining these positions in a future situation entails an uncertainty that resembles the uncertainty in granting a building permit (see above section 2): the time frame is immediate, variables should not change. The future situation can therefore, in the absence of uncertainty related to the current situation, be assessed based on current facts. On the basis of the current market situation and the current position of parties on the market, the joint position of the parties combined (at least immediately) after the concentration can be determined.

However, the possible effects on competition have yet to be determined. This substantive assessment relates to the question of whether the concentration will lead to a significant impediment to effective competition (step 3 of the assessment). This part of the assessment could be called the prospective analysis proper of merger control. The assessment of the consequences entails determining several possible futures and gathering information about probabilities in relation to those futures. To that purpose a 'theory of harm'25 is developed: an economic thesis regarding the consequences, mostly on consumer welfare, using models and economic theory. ${ }^{26}$

The three steps of substantive assessment of concentrations are, of course, interrelated: the future scenario contains an (economic) analysis based on an assessment of the current situation and position after concentration. Only after defining the relevant market and establishing the marketposition before the merger, the marketpositions after the merger can be determined. Only then the possible effects on competition can be evaluated. Now, as competition lawyers are aware, complicating this fairly simply sketched scheme of the three steps of merger assessment is, firstly, that an efficiency defence can be raised. Such an efficiency defence will claim that the merger will lead to efficiency gains that will offset the potential impediment to competition. ${ }^{27}$ An efficiency defence can, even though the evidentiary burden will shift (see also below), for the purpose of this article be seen as part of the third step of substantive assessment. Secondly, fairly often a proposal for remedies is part of the overall assesment as well. It could be argued that this is, conceptually, a fourth step in the assessment as the remedies will be assessed only after concluding on the possible effects on competition. If accepted, remedies are added as conditions to the authorization of the merger. This entails an assessment of whether the remedies proposed by the parties correct the established (though hypothetical) impediment of competition. Essentially, the question when assessing remedies is whether these problems can be prevented. Interestingly that means, in relation to establishing true facts, that a hypothetical solution to a future, also hypothetical problem is under assesment. In the remainder of this article efficiencies and remedies will 
not be discussed separately.

\section{Merger procedure specifics}

The discussion of establishing truth of facts in judicial review of merger decisions (in section 4) should be seen against the backdrop of some specifics of the merger-control procedure. Firstly, very short deadlines apply. ${ }^{\mathbf{2 8}}$ The terms can be, and in practice often are, extended, but there are limits. As indicated, these are final deadlines, which mean that if the ACM has not taken a decision the concentration will be deemed compatible and is allowed. Short time limits mean pressure-cooker procedures. Although the burden of proof is on the competition authority, it is the parties who need to provide information on the proposed merger, the markets involved, and the possible effects on competition. The competition authority has the obligation to ensure due process, to provide proper facts and to substantiate the decision: the burden of proof lies with the ACM, both in refusing and granting authorization. It has been pointed out that because the legal provision actually entails a negative condition (authorization is not granted if...), the duty to provide reasons is even stronger. ${ }^{\mathbf{2 9}}$ Of course, the evidentiary burden can shift: when invoking the efficiency defence, it is up to the parties to supply specific supporting evidence. ${ }^{\mathbf{3 0}}$ It is also up to the merging parties to propose remedies, though it remains the ACM's responsibility to substantiate the conditions imposed.

Secondly, the relationship between the merging parties on the one hand and the competition authority on the other is generally much less adversarial than in infringement procedures. Normatively a concentration is, in itself, a neutral event; very much unlike a cartel, for which a fine can levied. Legally this brings with it a symmetrical standard of proof: the standard of proof is the same for a refusal and for an authorization of a concentration..$^{31}$ And in a practical sense, this means that the competition authority (like the merging parties) will not be predisposed towards rejecting mergers. ${ }^{32}$ This is reinforced by the environment of 'trust', as the Court puts it, in which the procedure takes place. ${ }^{33}$ Usually the competition authority is consulted at a very early stage, often before the notification of the transaction. ${ }^{\mathbf{3 4}}$

These legal aspects (short deadlines, symmetrical standard of proof) and practical elements (procedure in which consultation, negotiation and trust are important) together result in the ACM being highly dependent upon the choice and quality of information and evidence brought forward by the parties. 35 Of course, a merger control procedure is not limited to the ACM and the merging parties; at the very least the ACM assesses proposed mergers, not in the interest of the parties but in the general interest of competition. Third parties - as affected parties - can also be involved in the procedure. In such instannces the characteristics sketched above may be somewhat muted. Clearly, though the practical and legal characteristics will not affect the formal division of burden of proof, they can affect underlying relationships, which in turn might affect remedies, which are usually shaped in a process of consultation and negotiation between the merging parties and the competition authority. All this is important because the overall substantive assessment of a merger contains several elements in which the ACM is given a certain leeway and discretionary room in judicial review (see section 4). The choices of the competition authority, also where there is a margin of appreciation, are made within this legal and practical context. 
As indicated, mergers are rarely completely prohibited. Not only are there relatively few transactions that complete the entire process of stage-one notification and stage-two application for authorization (which in the Dutch context are separated more than in the European context), but the majority of concentrations requiring authorization are eventually allowed, albeit often with remedies in place. ${ }^{36}$ The final decision can then be appealed; either by the parties involved or by a third interested party. It is to this stage of review that I will turn next.

\section{Merger control decisions before the court}

The merger assessment procedure, as previous sections have shown, entails a complex analysis: a 'multifaceted analysis with a wide range of relevant considerations interacting' ${ }^{37}$ It includes facts, the assessment of facts in the light of economic theory, a choice for economic theory or modelling where complex facts that are 'found' through economic analysis in turn are used as input for the next step in reasoning. ${ }^{38}$ It seems reasonable to suppose that this complexity impacts the review of the court. The court is expected to establish, or rule on the basis on, facts which are substantively true. In this section the specific aspects of judicial review of merger decisions will be discussed in light of the quest for judging on the basis of 'true' facts.

In appeal against merger decisions of the ACM, as is the case in other administrative competition cases, the general procedural rules of administrative law apply. These include legislative and judge-made rules on proof and evidence and rules relating to the review of administrative decisions by courts. Although in general before an appeal in court is possible, an internal 'administrative' appeal phase is required, this is not the case in merger control. ${ }^{39} \mathrm{In}$ light of the requirement of swift procedures in merger cases - as long as no authorization is granted, the merger cannot proceed - direct appeal against the decision of the ACM is possible first at the (district) court of Rotterdam, with the possibility for higher appeal at the Administrative High Court for Trade and Industry (College van Beroepvoorhet bedrijfsleven, or $C B b$ ). It is important to note that both courts are courts of facts: in both instances the substantive assessment and the procedural aspects of the merger procedure may be reviewed by the court, depending on the grounds of appeal (as not every appeal will contain substantive and procedural grounds). In both instances of appeal the ex-ante assessment of the ACM will be reviewed ex tunc by the judge, not ex post.

\section{Some general remarks on appeal in merger cases}

What exactly should be proven before the court (the probandum) follows from the statutory provision related to the assessment of mergers. The elements have been described above and do not differ from the European Competition law elements: as substantive assessment of mergers contain three conceptually distinct steps, evidence is required for all three of them. Grounding the merger decision should generally be:1) evidence on the facts of the current market situation and the position of parties on that market; 2) evidence regarding the factual future market situation; and 3) evidence regarding the prospective analysis, i.e. the charting of the future effects on competition. As mentioned above, economic theory and the use of economic models can play an important role. As a result the economic doctrines and the application thereof become a part of the evidentiary process before the court. In principle, the burden of proof 
rests upon the ACM (see section 3).

That leaves the standard of proof to be discussed. Generally speaking, when reviewing the facts that form the basis of an administrative decision for courts there is an imaginary scale that runs, on the one hand, from a mere review of facts as established by the administrative authority by the court, to, on the other hand, actual investigation as to the facts - thereby establishing the facts itself by the court. In Dutch administrative court proceedings it is possible for the court to go fact-finding itself; which means that in every case at the very least the facts can be fully reviewed by the court. Therefore at either end of the scale there is no discretion as to the facts, the difference lies in the possible active involvement in establishing facts and fact-finding or merely (fully) reviewing the facts as established by the authority. Of the several highest administrative courts in the Netherlands, whereas the Council of State (Raad van State) is very reluctant - leaning almost to a marginal review - and the Central Council (Centrale Raad van Beroep), dealing mostly with social security cases, seems much more active in engaging in establishing the facts, the $\mathrm{CBb}$ usually takes a position somewhere in the middle of this imaginary scale. It generally holds that as to facts, the substantive correctness of evidence is to be leading to establishing substantively true facts (see section 2). But the court also holds that in the division of labour between the administrative authority and the court, it is not the court who first finds the facts: the administrative authority must do so with due care, of which the result is laid down in the sufficiently reasoned administrative decision.

In general the standard of proof in administrative court procedures is that the facts should be 'sufficiently plausible' ('voldoendeaannemelijk'). Usually there is no further specification; the facts should be sufficiently substantiated for reaching the required standard of proof. This standard of proof seems to lie between the standard in civil law proceedings, which is lower (akin to a balance of probability standard), and criminal law, which is higher. In merger control the same general administrative law standard of proof is applied: as the CBb has held, the facts should be established with regard to due process and 'by plausibly demonstrating that the facts and circumstances meet the statutory requirements' ${ }^{40}$ However, these requirements, it is submitted, are dependent on the distinctive steps of substantive assessment, indicated above, used in merger cases. This distinction is not always present in the case law of Dutch administrative courts: assessment of the current market situation is not always separated from assessing the future situation. The two steps relating to the postmerger situation (position on the market post-merger and actual prospective analysis) are not always separated either: in the AMC/VZA-case the district court of Rotterdam assessed all three steps under the heading of 'prospective analysis' ${ }^{41}$ Of course, the three parts are interrelated. However, it is important to carefully indicate which part of the substantive assessment is under review: as will be further explained below, the different content of each of these analyses means that there are differences in being able to prove facts and establish substantive truth in court. In sum, the assessment of the merger decision relates to each of the three steps, which can be reviewed separately, but in the end also need to be reviewed as a whole..$^{22}$

Reviewing the facts relating to current situations: complex analyses

In this section I will try to distangle judicial review in relation to the first step of 
substantive analysis of a merger case, relating to the court's review of the facts related to the current market situation. This seems a simple matter: facts are facts, meaning that in the court's review of the facts there is no margin for discretion for the administrative authority. ${ }^{\mathbf{4 3}}$ Indeed, this should not be different for merger cases coming before the district court or the $\mathrm{CBb}$. But, on the other hand, this first substantive assessment-step already involves 'complex economic analyses', as labelled by the ECJ. ${ }^{44}$ The complexity relates both to the current position and current facts, but also includes an economic analysis - or economic qualification - of these facts. The assessment is therefore a mix of (more or less simple) facts with economic theory, which morph into new, clustered and thus more complex facts. The findings reached using economic models and economic theory are in turn interpreted in light of the legal provision, leading to a certain (legal) qualification in relation to the current market situation.

This can be illustrated by the relatively simple example of determining the position of merging parties on the market. Determining the relevant market (a legal concept with an economic dimension) is done by combining facts and economic theory, ${ }^{45}$ most commonly by using the SSNIP-test. The test is based on the premise that substitutes for the goods or services in question exert competitive pressure, tested by measuring whether consumers switch to a different product or service when confronted with a small (hypothetical) increase (or decrease) in price. This serves to define a relevant market. Data submitted by the parties and other market participants (for example turn-over), provide insight into the position of the parties on the market. This position can be qualified as a 'weak' position, or as a dominant position, taking into account not just the interpretation of the legal concept of market dominance, but also considered in the light of common economic theories. Sometimes this qualification is more complicated, for example, when opting not for the standard SSNIP-test but using other economic theories, such as the Elzinga-Hogerty test. ${ }^{46}$

But market definition already can give rise to heated debates. ${ }^{47}$ A case in point is the discussion with regard to the market definition of the relevant market of hospitals. The healthcare market is, of course, a market with specific characteristics since it is - in the Dutch context - in a transitional phase. Competition has been (partly) introduced, but the competition law assessment of mergers is undertaken for a market in which non-competitive interests may be regulated, and at the very least play a very important role. ${ }^{48}$ The discussion related to hospital services then, cocerns first, whether the relevant market is a general market for 'hospital care' or whether the market needs to be specified further, for example either by markets for different medical specialties or by splitting emergency and non-emergency care into two different markets. 49 Secondly, the relevant geographical market is also a point of debate. The 'simple' facts - which services does the hospital offer, which medical specialties are available, is there both emergency and non-emergency care, is the hospital an academic hospital with teaching and research facilities - remain the same, but the choice for a specific theory can yield a different outcome when determining the relevant market. Here the ACM has been criticized for determining the relevant market using outdated models, which did not take into account the changing market circumstances. ${ }^{\mathbf{5 0}}$ Hence, policy developments not only had an impact on the factual situation but, it was stated, they should lead to a different market definition. Obviously, if the relevant market changes, or is delineated differently, the basis on which the merger is assessed alters as well..$^{\mathbf{1}}$ 
Courts tend to keep a certain distance, at least on paper, to the administrative authority in relation to combined questions of fact and qualification. The ACM, in competition cases, is granted 'a certain margin of discretion' ('eenzekerebeoordelingsvrijheid').52 This is, in the Dutch context, a 'new' formulation: it is only slightly differerent from the words generally used to grant discretion in the case of such combined questions; added is that there is 'a certain' margin and not just 'a margin of discretion' ('beoordelingsurijheid').53

The certain margin of discretion primarily concerns the assessment of the facts in light of economic theory. The court fully reviews 'the substantive validity of the elements of evidence'. The court also needs to 'assess whether those elements [the submitted evidence] form the relevant factual framework for the assessment and whether or not the evidence can support the conclusions drawn from it'.54 In other words, the review not only involves the question whether the facts are correct - the substantive truth - but also whether the facts are relevant for the assessment. This includes the selection of facts. The question arises whether the administrative authority also has a certain margin of discretion regarding this selection. To be able to review whether the selection of facts was a correct selection, all of the facts (also the facts that were not selected) need to be known. This is an impossible task, nor is it certain that this is implied by the Dutch $C B b$ : the review of selection of facts seems to relate to whether the facts are the right facts for the analysis that is applied. Of course, it then becomes necessary to know which facts are the relevant facts; a question that can only be answered by reviewing the model that has been used. The model or theory decides, at least in part, the set of facts. This entails that the review relating to the selection of facts is not a marginal review - in the Dutch context that would be difficult to fit in with the general scheme in which facts are almost always reviewed in full - but somewhere between a full and marginal review.

The first step of a substantive analysis of a proposed merger comprises a complex economic analysis, which in its totality is reviewed somewhat less than full as a result of the 'certain margin of discretion'. The distance of the court to the facts is, however, not very large as the review entails a full review of the correctness of the facts established, a full review of whether these are the right facts for the applied analysis, and a full review of the correctness of the relationships between the facts as brought forward by the administrative authority. The review also comprises the question whether the facts can support the conclusions that are drawn from them. It is there that the 'certain margin of discretion' can be found. The above leads to the conclusion that in principle it is possible for the court to establish the substantive truth. The formal truth, as established by the judgment, could indeed coincide with the substantive truth, although admittedly in practice this will be difficult due to the complex reasoning involved.

\section{Reviewing the facts relating to the position post-merger: future, but not complex}

The second step of the substantive assessment in merger control regards determining the position of the parties on the relevant market post-merger. Though clearly at the time of the assessment of the merger this part relates to future facts - the merger has yet to take place - in theory there is little uncertainty. This is certainly true if this step is taken in isolation, but of course, if complexities involved in the first step lead to uncertainties there, this 
uncertainty will inform the second step as well. Still, the market position of parties post-merger directly follows the first step of which the correctness could, in principle, coincide with the substantive truth, as noted above. In general there is little uncertainty between the two: one takes the step from here (before the merger the market share of one party is $\mathrm{x}$ and the market share of the other is $\mathrm{y}$ ) to there (after the merger the total market share is $\mathrm{x}+\mathrm{y}$ ) and that step is entirely based on facts from the first step. Hence, the determination of the position of parties on the market after the concentration can be based on current facts as there should generally be no additional variables that can disrupt that inference. ${ }^{55}$ This means that although in principle substantive truth of future facts cannot be determined, this has no impact here: the formal truth may approximate the substantive truth closely.

\section{Reviewing the facts for the effects on competition: future and complex prospective analysis}

The third step in the substantive assessment in merger control is the analysis of the effects in competition of the merger. This is the prospective analysis proper. Clearly the concepts of 'prospective analysis' and 'substantive truth' are hard to combine: the truth - in the sense of 'that what actually happened' - cannot be determined, leading to real-world uncertainty. A prospective analysis also contains uncertainty in the legal sense. This is acknowledged by the $\mathrm{CBb}$, stating that prospectivityinvolves a 'different certainty'. That a prospective analysis is aimed to establish future facts requires a different form of review of this part of the mergerdecision. In this setting, the $\mathrm{CBb}$ has held that a prospective analysis needs to be executed with due care..$^{\mathbf{6}}$ It needs to be based on facts and circumstances from before the merger, which have passed the required standard of proof of being 'sufficiently plausible' (voldoendeaannemelijk).57 This care that is due, I would expect, pertains to both the substantive correctness of the current facts (mainly the facts from the first step of the assessment) and the care that is taken by the analysis and the study of future events..$^{8}$ This analysis needs to examine both which causes can lead to which possible effects and the identification of the most probable scenarios. 59 The duty of care thus entails the careful mapping of different scenarios, their underlying principles, and the consistency of inferences within the scenarios. ${ }^{\mathbf{6 0}}$ So far, in judicial review by the courts, it has not been made explicit that the review also covers the selection of the scenario chosen as ground for the final merger decision. This seems quite self-evident, although the intuitive analogy with the correct selection of facts (above) may not be completely valid; the certainty of establishing which facts are the correct facts in light of the economic model chosen may be a greater certainty than whether the chosen scenario is the correct scenario that was selected (the analogy is closer to the review of which economic model to choose, on which more below). ${ }^{\mathbf{6 1}}$ It seems that not necessarily all possible scenarios should have to be substantiated to be sufficiently justified, but there needs to be substantiation to justify the choice of the most probable scenario. ${ }^{\mathbf{6 2}}$ This choice can be reviewed, although a certain margin of appreciation for the ACM seems logical here (but has not explicitly been established by the reviewing courts). Still, from European case law it can be deduced that despite a symmetrical standard of proof if the theory of harm on which the assessment is based is less probable, a higher standard of proof, or at least of reasoning, is indicated. For example, if negative effects are assumed in a conglomerate merger case, which in general are not regarded as being detrimental to competition, more convincing evidence is necessary than would be the case generally. ${ }^{\mathbf{6 3}}$ However, this 
difference seems to be difficult to apply in practice.

The $\mathrm{CBb}$ has accepted that scenarios relate to a period of three to five years. This timespan includes countless variables, resulting in an analysis with exponential uncertainty. If remedies are attached to the merger, an additional assessment of the precise requirements is needed: can the remedies, hypothetically, take away the anti-competitive effects? This adds an additional element of uncertainty to the analysis. In general it seems that although the uncertainty in relation to facts can, and should be, limited to those parts of the merger analysis that actually contain uncertain events, a substantive truth in relation to prospective analysis cannot be established. After all, an assessment that meets all the requirement of due care and process, that is complete and contains clear reasoning and inferences, and in which the conclusions are consistent with the findings, can only approximate the substantive truth. The timespan and influence of (interrelated) variables that come with it (which cannot be charted in advance) imply that substantive truth cannot be determined that way, but that a formal truth is established by the courts' judgment.

\section{Some complications}

Establishing truth is a complicated and difficult exercise in each of the different steps in merger control review. This is a result of both the procedural and the legal-economic context. As noted, part of the evidence is provided by the merging parties and short, final deadlines apply in procedures at the competition authority. The Court of Justice (in relation to the Commission), has ruled that it cannot be expected that the Commission checks the validity of each and every detail of evidence. ${ }^{\mathbf{6 4}}$ If this is true also on a national level, this may shift the focus from establishing the facts at the level of the competition authority to the level of the court. Other elements in the procedure also point towards this tendency, for example that in Dutch merger control, the internal appeal procedure (at the competition authority) is abandoned. The fact that much of the material is provided by merging parties also warrants a critical review in appeal. ${ }^{65}$ The same holds true for information provided by competitors, which suffers from similar reliability issues, ${ }^{\mathbf{6 6}}$ and for information provided by consumer surveys. ${ }^{67}$ These elements together could force courts to shift towards a more stringent review on the imaginary scale or to take a position in finding and determining the facts itself. however, in the Dutch administrative legal context, where there is a limited role for the (relatively) short courthearing, there is not much room for a practice of hearing testimonies and discussing each piece of evidence. Also, a more stringent review of facts does not sit well with the margin of discretion awarded to the competition authority.

There are other complications. Competition law is economic law and, as sketched above, input from economics plays an important role in virtually each step of the substantive assessment of a merger. ${ }^{\mathbf{6 8}}$ This has consequences for the possibility to establish true facts. For example, the choice for a certain theory or model can be an important element in the assessment. ${ }^{69}$ This choice also has consequences for the selection of facts: what the relevant facts are, will (partly) be defined by the model. $7^{\mathbf{0}}$ But how should the theory or model itself be seen by the reviewing court? Whereas in philosophy of science, falsification of a theoryas long as a theory is not falsified it is considered to be true - seems to be the norm, in a legal context it seems difficult to speak of the 'truth' of the theory or model. ${ }^{71}$ Review of the choice, asking the question whether the choice is a choice 
for the 'right' theory, becomes complicated also because it is difficult to label a theory or model itself as 'fact', though of course complex facts rest on the input of simple facts and the theory does use facts as input. Also, as an abstraction and in essence, a model or theory always leads to a reduction of the truth, even when the result does model true facts. Thus, establishing the 'truth' of a theory or model itself seems ill-fitting. But neither is the model or theory itself a matter of qualifying facts in the legal sense of that word: the model does function as part of the factual construct of the merger decision. It seems, then that labeling models and theories as part of the evidence, would also means that 'evidence' relates to more than just facts. ${ }^{\mathbf{2}}$

The above also leads to the conclusion that judicial review of a theory or model cannot easily follow the same logic as reviewing facts, nor the same logic as reviewing a legal qualification. This means that establishing substantive truth becomes especially difficult, almost twice removed from 'that which actually happened'. ${ }^{73}$ Taking the standard of proof as substantiated plausibility, what exactly must be shown to be plausible to not succumb in the judicial review procedure? I would suggest that in the context of Dutch administrative law, the choice for a certain model or theory needs to be left to the regulator. ${ }^{74}$ In this, there should be a margin of discretion. However, the general requirements as posed by the Dutch $\mathrm{CBb}$ in relation to judicial review do apply here as well: the model should be a realistic reflection of the behaviour by the parties on the relevant market in question and a high level of transparency needs to be attained. ${ }^{75}$ Furthermore, from case law of the ECJ one can add that 'the more speculative the theory, the more compelling the evidence needs to be'. ${ }^{\mathbf{6}}$ This, of course, requires an assessment by the court on the speculative nature of the theory chosen and, subsequently, an assessment of the compellingness of the evidence. This does not necessarily imply a higher burden of proof (a higher degree of plausibility), as that seems contrary to the speculativeness of the theory chosen, but rather a more demanding review of both the arguments for choosing the speculative model and, I presume, the robustness of the facts. ${ }^{77}$ Interesting in this regard is the plea for evidence-based antitrust enforcement, where the principle is posited that the competition authority should opt for the best available economic theory. That means choosing the economic theory which has been empirically proven to be sound. ${ }^{\mathbf{7 8}}$ In terms of substantive truth: it is not necessary to use the one true theory - elusive at best - but the 'truest' theory. In judicial review this means assessment by the court of the empirical soundness of both the theory that has been used, but possibly also a review of the arguments in relation to this choice meaning a comparison between theories and their respective soundness.

Judicial review thus covers the question to which extent the theory or model is speculative (which implies an assessment of the current state of economic science). It also includes to what extent the model or theory has proven itself empirically. In case of a speculative theory or a non-empirically proven model the reason for opting for such a theory or model needs to be substantiated. This also comprises the question whether another adequate theory exists, which is less speculative. Furthermore, judicial review involves reviewing whether the model or theory is a realistic depiction of the behaviour of market parties (the 'fit' of the model/theory on the specific case). ${ }^{79}$ The court should also review whether the right - and sufficiently plausible - facts are used for the application of the model or theory in the specific merger case. This also comprises the application of the model or theory on the specific case, which should be 
undertaken with utmost transparency of each of the choices involved. Each of these elements requires insight and knowledge of economics and the current state of economic science.

\section{Conclusion}

Is it illusionary to expect the court to find substantive truth in merger cases? The answer must be nuanced. Yes, because of the prospective analysis establishing substantive truth is impossible: the truth of a future event cannot be determined if truth is seen as 'that what has actually happened'. But by carefully dissecting the steps involved in establishing facts in merger decisions taken by the competition authority, pondering the nature of the evidence presented in court and the context in which judicial review in court takes shape, it is possible to reduce uncertainty to the part of the assessment that actually is a prospective analysis. The difference between substantive truth and the formal truth established by the court becomes apparent here. The court's search for the truth indeed revolves around justification of the weighing of evidence and proof within the procedural context of the case. Therefore two theories regarding truth need to be joined: regarding current facts, substantive truth and legal truth should lie closely together and the correspondence theory of truth can be used to explain legal truth. But for the prospective analysis proper it is necessary to merge correspondence with coherence. The formal truth of facts in the judicial review of a merger decision rests on reviewing the evidence related to prospective analysis, ${ }^{\mathbf{8 0}}$ but in close in connection with all other elements of the assessment. In this way formal and substantive truth may never meet, but are closely connected nonetheless.

\section{Noten}

1 J.B.M. Vranken, Mr. C. Assers' Handleiding tot de beoefening van het Nederlands Burgerlijk Recht, Algemeen Deel, Deventer: Kluwer 2005, p. 14 (translation of the author).

2 Act of 28 February 2013, concerning the rules regarding the establishment of the Authority Consumer \& Market (Autoriteit Consument \& Markt, or ACM) Stb. 2013, nr. 102. Note that in the decisions of the 'old' competition authoritity the abbreviation used, also in this article, is 'NMa' (Nederlandse Mededingingsautoriteit)

3 Also: M. Loth in: Preadviezen NJV, 'Waarheid en waarheidsvinding in het recht', Deventer: Kluwer 2012, p. 40-41.

4 See M. Loth 2012.

5 See Gerbrandy 2012, p. 160-162. The correspondence theory of truth means that a statementis 'true' if it corresponds with the truth, that is, if it accurately describes reality. The theory thus presumes the existence of 'the' truth and also that this truth can be known. The correspondence theory is often compared to the coherence theory in which the truth of a statement depends upon its relation to other statements.

6 However, for a nuance on the notion that civil law revolves around formal truth and not substantive truth, see R.H. de Bock, Tussenwaarheid en onzekerheid: over het vaststellen van feiten in de civiele procedure (diss. 
Tilburg), Deventer: Kluwer 2011.

7 See on the administrative law of evidence Y.E. Schuurmans,

Bewijslastverdeling in het bestuursrecht (diss. VU), Deventer: Kluwer 2005.

8 T. Barkhuysen e.a., Derde Evaluatie van de Algemene Wet Bestuursrecht 2006. Feitenvaststelling in beroep, Den Haag: Boom Juridische uitgevers, 2007.

9 On these elements see Gerbrandy 2012, p. 159-169.

10 E.g. CBb 6 December 2010, LJN BO6663 (Loodsentarieven); OPTA Tariefbesluit WLR-C (UPC en Ziggo) 10 March 2010, OPTA/AM/2010/200749.

11 See for example the decision of the Minister of Economic Affairs, Agriculture and Innovation on the nuclear powerplant Borssele (Besluit Kernenergiewetvergunning verleend aan de N.V. Electriciteitsproductie-maatschapij ZuidNederland (NV EPZ) ten behoeve van brandstofdiversificatie Kerncentrale Borssele, 24juni 2011).

12 E.g. Province of Limburg, Raport VerkeerOntwikkelas Weert-Roermond, studie N28o-West, 17 augustus 2011.

13 On the fundamental uncertainty of predictions, see alsoN.N. Taleb, Fooled by Randomness, The Hidden Role of Chance in Life and in the Markets, New York: Random House 2004.

14 Elsewhere I posited that it was logically impossible to determine a future substantive truth. This turns out to be incorrect: especially within logic it is very well possible to come to substantively true statements with regard to future events.

15 Substantive norms of Dutch competition law are copied from European competition law. On the influence of this fact on the administrative judge, see: A. Gerbrandy, Convergentie in het mededingingsrecht (diss. Universiteit Utrecht), Den Haag: Boom Juridischeuitgevers 2009.

16 In this article I analyze the Dutch administrative legal context. Due to the one-stop-shop principle in merger control, the administrative judge will only aply Dutch merger provisions. However, I (also) refer to European case law (and literature). These legal 'precedents' do not have a formally binding force for national merger control (see Gerbrandy 2009, p. 328-329); however, they are an important source for legal development, since the substantive norms of Dutch merger control are almost identical to those of European merger control. Since the analysis presented here does not aim towards explaining differences (or influences) between the two legal systems, it is submitted that the references to the European context have value for the analysis presented here.

$\mathbf{1 7}$ The procedure consists of two phases: the notification phase, in which the ACM is notified about the merger proposal, and the authorization phase, in which the aplication for authorization is processed - but of course only when the ACM has decided that authorization is needed. This is somewhat different from the European merger control procedure, where the second phase does not start with a formal and new aplication for authorization. The substantive assessment 
of the proposed concentration is however, in principle, the same in both phases, although the certainty of the findings differ as the first phase only contains a preliminary assessment.

18 Article $41 M w$.

19 Article $44 M w$.

20 For example, in the NMa decision nr. 3897, Ziekenhuis Hilversum ZiekenhuisGooi-Noord. Also see, M.Ph.M. Wiggers, De NMa en de NZa in de curatievezorgsector (diss. KUN), Deventer: Kluwer 2013, p. 254-263. But also see: G.J. Werden, 'Why (ever) define markets? An answer to Professor Kaplow', SSRN 13 February 2012.

21 On the various models, see I. Lianos \& Ch. Genakos, Econometric evidence in EU competition law: an empirical and theoretical analysis,CLES Working Paper Series nr. 6/2012, p. 26-29.

22 On the distinction between 'simple' facts and 'complex' facts see Gerbrandy 2009, p. 91.

23 See NMa decision nr. 3897, Ziekenhuis Hilversum - Ziekenhuis Gooi-Noord.

24 SSNIP stands for 'Small but Significant Non-transitory Increase in Price', a test to see which products or services belong to the same market as the product or service under scrutiny (see the Commission Notice on the definition of relevant market for the purposes of Community competition law, OJ C 372, 9 December 1997, p. 5-13).

25 'A well-developed theory of harm has the following characteristics: it should pinpoint how competition and, ultimately, consumers will be harmed relative to an apropriately defined counterfactual condition; it should be internally logically consistent; it should be consistent with the incentives that the various parties face; and it should be consistent with (or at least not inconsistent with) the available empirical evidence', state H. Zenger \& M. Walker, Theories of Harm in European Competition Law, A Progress Report, SSRN, 22 February 2012.

26 For an overview of the different methods, see Lianos \& Genakos 2012, p. 2941; and also G.J. Werden \& L.M. Froeb, 'Choosing among tools for assessing unilateral merger effects', Vanderbilt Law and Economics Research Paper nr. 19/2011.

27 SeeT.W.P. van Dijk, 'Efficiëntieverbeteringen in concentratiecontrole', $M \& M$ 2009-2, p. 83-88.

$\mathbf{2 8}$ For instance, the ACM has four weeks to decide - in the first phase - upon whether a second phase investigation is necessary (article 37 (1) and (5) Mw).

29 Specifically on article $41 M w$ see Gerbrandy 2009, p. 343; and more in general see Y.E. Schuurmans 2005, p. 194.

30 The European Commission also refers to these criteria in the Guidelines on the assessment of horizontal mergers under the Council Regulation on the 
control of concentrations between undertakings(2004/C 31/03)

OJ C 31, 5 February 2004 at par. 76-88).

31 See Lianos \& Genakos 2012, p. 77; also Gerbrandy 2009, p. 336-342; M.F. Bay \& J. Ruiz Calzado, 'Tetra Laval II: The Coming of Age of the Judicial Review of Merger Decisions', World Competition 2005, p. 433-453; K. Wright, 'Perfect Symmetry? Impala v Commission and Standard of Proof in Mergers', European Law Review 2007-3, p. 408-418.

32 Support for this statement can be found in a study by F. Maier-Rigaud \& K. Parplies, 'EU merger control five years after the introduction of the SIEC test: what explains the drop in enforcement activity?', European Competition Law Review 2009-11, p. 565-579. They conclude that since 2004 (up to 2008) just $0,1 \%$ of the notified concentrations was prohibited (compared to the $1,0 \%$ in 1994-2003). Since the European Merger Regulation, which came into effect in 1990, a 'mere' 22 of the 4600 proposed concentrations have been blocked by the Commission, according to Eurocommissioner Joaquín Almunia. See http://europa.eu/rapid/press-release_SPEECH-12-773_en.htm; and alsosee the table in Lianos \& Genakos 2012, p. 111; M. Canoy, 'Zorgfusies: gekker moet het niet worden', Markt en Mededinging 2008-6, p. 191-192.

33 Judgment of 13 July 2006, Case T-464/o4 (Impala/Comission), ECR 2006 p. II-2289, par. 415.

34 See 'Spelregels bij concentratiezaken', p. 4; last modified on 26 April 2013, at www.acm.nl.

35 The ACM has its own Economic Division under the supervision of a Chief Economist.

36 Also see Maier-Rigaud \& Parplies 2009.

37 A. Bavasso \& A. Lindsay, 'Causation in EC merger control', Journal of Competition Law and Economics, 2007-2, p. 181-202, at p. 182.

38 Y. Botteman, 'Mergers, standard of proof and expert economic evidence', Journal of Competition Law and Economics 2006-1, p. 71-100, at p. 73.

39 'Internal administrative appeal' (bezwaar) meaning that it is the ACM itself that will take a revised decision, taking into account the grounds of the applicant.

$40 \mathrm{See} \mathrm{CBb} 28$ November 2006, LJN AZ3274 (Nuone.a./NMa).

41 District court of Rotterdam 24 February 2011, LJN BP5712 (OLVG en St. Lucas Andreas/NMa).

42 See Judgment of 27 September 2006, case T-44/02 (Dresdner Bank/Commission), ECR 2006, p. II-3567.

43 See Gerbrandy 2012; cf. judgment of 14 December 2005, case T210/o1(Honeywell/Commission), ECR 2005, p. II-5575,par. 62; B. Vesterdorf, 'Standard of proof in merger cases: reflections in the light of recent case law of 
the Community courts', European Competition Journal 2005-1, p. 3-33.

44 See Gerbrandy 2009, p. 116-126.

45 For instance, in the market analysis regarding the merger of two abattoirs by doing regression analysis on export volumes and factual price differences between the Netherlands and Germany; see District Court of Rotterdam, 19 April 2007 LJN: BA3538 (NVV en NBHV/NMa).

46 See, for instance, H.E. Frech III, J. Langenfeld \& R.F. McCluer, 'ElzingaHogarty Tests and Alternative Aproaches for Market Share Calculation in Hospital Markets', Antitrust Law Journal 2004-3, p. 921-947.

47 Also see: District Court of Rotterdam, 25 August 2011 LJN: BT8903 (NMV en NBHV/NMa) and District Court of Rotterdam 19 July 2012 LJN: BW4162 (NMV en $N B H V / N M a)$.

48 See generally Wiggers 2013; E.E.C. van Damme, 'NMa, Zeeuwse Ziekenhuizen en het algemeen belang', Economisch Statistische Berichten, 1 May 2009, p. 271.

49 See for example J.J. Rijken, 'Concentratie van ziekenhuiszorg - iemand moet het doen, maar wie?',Tïjdschrift voor Gezondheidsrecht 2011 (35) 7, p. 544-559; E.M.H. Loozen \& M. Varkevisser, 'Mededingingsanalyse verticale concentratie ambulancezorg: uitspraak Rechtbank Rotterdam te kort door de bocht', Markt en Mededinging 2011- 4, p. 140-144.

50 Loozen \& Varkevisser, p. 143; C.T. Dekker, E. Belhadj \& E. Hameleers, 'Kroniek rechtspraak mededingingsrecht', Tijdschrift voor Gezondheidsrecht 2013-1, p. 39-58.

51 In the GooiseZiekenhuizen case the competition authority was criticised for establishing the relevant market too broadly, which implied higher competitive pressure, which in turn would reduce the chance of anti-competitive behavior occurring: see Canoy 2008; Wiggers 2013, p. 254-263.

$52 \mathrm{CBb} 27$ September 2002, LJN AE8688 (Essente.a./NMa); CBb 28 November 2006, LJN AZ3274, (Nuon e.a./NMa).

53 For completeness' sake it is added that this type of marginal review must be discerned from the policy discretion ('beleidsvrijheid') that may also accrue to administrative authorities. The latter relates not to assessment of facts, but to the consequences of infringement: for example, the choice of measures of redress. In this article policy discretion is not discussed.

54 Although the $\mathrm{CBb}$ has formulated this assessment-standard in an authorization case (the second phase), the district court at least also regards this standard aplicable to decisions in the first phase.

55 But see for an exception the electricity merger case where the determination of market shares was in fact very complex. The court stated that the circumstance that such an investigation was possibly not easy to perform cannot be shift onto the plaintiff (District Court of Rotterdam, 1 June 2005 LJN AT8794 
( $X$ and $Y / N M a)$.

$56 \mathrm{CBb} 28$ November 2006, LJN AZ3274 (Nuone.a./NMa), par. 8.3.4.

$57 \mathrm{CBb} 28$ november 2006, LJN AZ3274 (Nuone.a./NMa), par. 8.3.3.

58 This also includes legislation that has yet to come into effect (and the consequences thereof for the market), e.g. the introduction of competition in the market for health insurances in District Court of Rotterdam, 7 December 2012 LJN AU9053 (Stichting CZ ZorgverzekeringenBeheer/NMa).

$59 \mathrm{CBb} 28$ November 2006, LJN AZ3274 (Nuone.a./NMa) par. 8.3.4. The Commission makes studies on possible scenarios: cf. judgment of 14 December 2005, case T-210/o1(Honeywell/Commission), ECR 2005, p. II-5575, par. 429.

60 The underlying principles can be prospective as well. See, for instance, the 'points of departure' for the assessment of the joint venture of KPN and Reggefiber: there the presumption that in a certain area only one network of glass fibre could be put in place, was made based on another presumption that at least $50 \%$ of all households would have to be connected to the network to make the exploitation profitable. These principles carry a prospective element and then form the basis for the 'prospective analysis': two scenarios regarding the consequences of the concentration: District Court of Rotterdam, 18 November 2010 LJN BO4372 (Ziggo en UPC/NMa).

61 See for instance District Court of Rotterdam, 18 November 2010 LJN BO4372 (Ziggo en UPC/NMa), where the court reviewed two sceneriosbrought forward by the NMa. The court did not, however, explicitly address the question whether these were the right scenarios.

$62 \mathrm{CBb} 28$ november 2006, LJN AZ3274 (Nuone.a./NMa), par. 8.3.4;

Judgment of 25 October 2002, case T-5/02(Tetra Laval/Commission), Jur. 2002 p. II-04381, at par. 155 and par. 223.

63 A.L. Sibony, 'Limits of Imports from Economics into Competition Law', in I. Lianos \& D. Sokol, The Global Limits of Competition Law, Stanford: Stanford University Press 2012, p. 39-53, at p. 50-53.

64 See above case T-464/o4 (Impala/Commission).

65 Cf. P. Massey, 'Commission's economic analysis shoots down Ryanair's proposed acquisition of Aer Lingus', Competition Press Conference 30 april, (http://www.compecon.ie/PM\%20Aer\%20Lingus\%20Ryanair.pdf); and more generally also see J. Golding, 'The Impala case: a quiet conclusion but a lasting legacy', European Competition Law Review 2010-7, p. 261-267.

66 Maier-Rigaud \& Parplies 2009, p. 574.

67 See D.S. Tucker, S.L. Reiter \& K.L. Yingling, 'The customer is sometimes right: the role of customer views in merger investigations', Journal of Competition Law and Economics 2007-4, p. 551-607.

68 This also means that economic experts play an important role. I will not 
further discuss this (extra) complication here.

69 Cf. also Werden \& Froeb 2011.

70 This already comes up in the determination of a relatively simple 'theory of harm' which in turn could determine what the 'most plausible' relative market is; see District Court of Rotterdam 24 February 2011, LJN BP5712 (OLVG en St. Lucas Andreas/NMA).

$\mathbf{7 1}$ 'Economic models are maps for the market economy. A map can be false, but never true', J. Kay, The Truth About markets, London: Penguin Books 2003, p. 193 .

72 See on the 'agnostic' stance of the law regarding what is considered as evidence Lianos \& Genakos 2012, p. 81.

73 See for instance the criticism on the use of diversion ratios by the British Competition Commission by

U. Akgun \& D. Ridyard, 'Lost in translation: the use and abuse of diversion ratios in unilateral effects analysis', European Competition Law Review 200610, p. 564-568; criticism on the use of 'traditional models' with a 'bias' D.L. Weisman, 'Assessing market power: the trade-off between market concentration and multi-market participation', Journal of Competition Law and Economics 2005-2, p. 339-354; proposals for different modeling in determining the relevant market for the market of internet access A. D'Ignazio\& E.

Giovanetti, 'Antitrust analysis for the internet upstream market: a border gateway protocol aproach', Journal of Competition Law and Economics 2006-1, p. 43-69.

74 Regarding the model-selection problem also see J.D. Wright, 'Evidence Based Antitrust Enforcement in the Technology Sector', CPI Antitrust Chronicle, March 2013, p. 1-14.

$75 \mathrm{CBb} 28$ November 2006, LJN AZ3274 (Nuone.a./NMa), par. 8.3.4.

76 K. Platteau, 'Nogmaals over conglomerale concentraties, bewijslast en rechterlijke toetsing. Enkele juridische kanttekeningen bij het arrest General Electric/Commissie', Markt en Mededinging 2006-2, p. 53.

77 Arguments require more evidentiary suport if they go against 'mainstream economics'; see Lianos \& Genakos 2012, p. 77-78.

78 Wright 2013.

79 Regarding this 'fit' also see Werden \& Froeb 2011, p. 25-26.

80 Cf. also H.L. Ho, A Philosophy of Evidence Law: Justice in the Search for Truth, Oxford: Oxford University Press 2008, p. 161-162. 
